\title{
Biodiversity and Vulture-Canid Relations
}

Michael O'Neal Campbell*

*Corresponding author: Campbell, M.O'Neal, Simon Fraser University, British Columbia, Canada, Tel: 2508163784; E-mail: ecol55@hotmail.com

Received date: January 1, 2015; Accepted date: January 2, 2015; Published date: January 12, 2015

Copyright: (c) 2015 Campbell M, et al. This is an open-access article distributed under the terms of the Creative Commons Attribution License, which permits unrestricted use, distribution, and reproduction in any medium, provided the original author and source are credited.

\section{Introduction}

The dominance of some species over other less dominant competitors may reduce biodiversity, and the the comparative ability of the latter species to adapt is crucial area of study for ecology. Scavenging, a major ecological activity, attracts competitors within dominance hierarchies. Vultures, the dominant 'full time' or obligate scavengers, must compete with mammalian, 'part time' or facultative scavengers such as canids (members of the dog family, including wolves, coyotes, jackals and foxes). The success of vultures in such relations depends on their relative (compared with the facultative scavengers) size, strength and predatory characteristics. Vulture characteristics are dependent on their evolutionary history. There are two main groups of birds termed as vultures, the New World Cathartid vultures (possibly related to or evolved from storks, but this is still debated, ranging in North and South America) and the Old World Accipitrid vultures (related to or evolved from eagles and hawks, ranging in Eurasia and Africa).

The Cathartid and Accipitrid vultures have common and varied characteristics. Common attributes of all but two vulture species are featherless or nearly featherless heads/necks, obligate or specialized scavenging (rather than facultative or part time scavenging), soaring flight, and with scientific investigation, the possession of long intestines, strong stomach acids for the digestion of carrion and weaker feet than the predatory raptors $[1,2,3]$. The New World Cathartids differ from the Old World Accipitrid vultures in among others; thermoregulation (like storks, they defecate on their legs and feet for cooling purposes, termed urohidrosis); clawed but weaker feet [4]; different leg and pelvic muscle anatomy; and a comparatively weaker bill $[5,6]$.

\section{Vultures and Canids}

In terms of the relationship between both types of vultures and other scavengers, an under-studied hypothesis is that the raptorrelated ancestry of the Accipitrid vultures enables more eagle-like strength than that of the Cathartid vultures. It is possible that the former group has stronger competitive ability against scavenging canids. Canids are dominant facultative scavengers $[7,8]$. For such a comparison to be made, the canids used for comparison in the Old and New Worlds must be approximately similar in size and behavior. Similarly sized canids (coyotes and jackals) share the ranges of most of the vultures, hence a comparison of the ability of vultures to compete with them may reflect the relative strengths of the Cathartid and Accipitrid vulture species. Table 1 shows the comparative sizes of the large New World (in bold) and Old World vultures and the canids (the coyote is the only New World canid considered).

\begin{tabular}{|l|l|l|l|}
\hline Vulture & Length $(\mathbf{c m})$ & Wingspan (m) & Weight (kg) \\
\hline Andean Condor & $100-130$ & $2.7-3.2$ & $8-15$ \\
\hline California Condor & $109-140$ & $2.5-3$ & $7-14.1$ \\
\hline Cinereous Vulture & $98-120$ & $2.5-3.1$ & $6.3-14$ \\
\hline Himalayan Griffon & $109-115$ & $2.6-3.1$ & $8-12$ \\
\hline Lappet-faced Vulture & $78-115$ & $2.5-2.9$ & $4.4-13.6$ \\
\hline Griffon Vulture & $93-122$ & $2.3-2.8$ & $6.2-11.3$ \\
\hline Ruppell's Vulture & $85-103$ & $2.26-2.6$ & $6.4-9$ \\
\hline Cape Vulture & $96-115$ & $2.26-2.6$ & $7-11$ \\
\hline Canid & Length body, tail (cm) & Shoulder height (cm) & Weight (kg) \\
\hline Coyote & $76-86,30-41$ & $58-66$ & $6.8-20.9$ \\
\hline Side-striped Jackal & $69-81,30-41$ & $35-50$ & $6.5-14$ \\
\hline Black-backed Jackal & $60-90,26-40$ & $30-48$ & $6.8-9.5$ \\
\hline Golden Jackal & $70-85,25$ & 40 & $8-10$ \\
\hline
\end{tabular}

Table 1: Comparative sizes of the New and Old World Vultures 
Page 2 of 2

The New World Vultures and the Coyote are from the Americas, the rest are from Eurasia and Africa. The coyote is dominant over the California Condor at carcasses $[9,10]$. A reintroduced condor was killed by a coyote [11] and coyotes among other predators are implicated in 18 condor deaths [12]. The relation between the jackals and the largest Accipitrid vultures (with a size ratio similar to that of the condors and coyotes) is more even than that between coyotes and condors. Black-backed and Golden Jackals in Africa and Eurasia "compete heavily with vultures" [13]. In some cases as well, the larger vultures may attack jackals at carcasses [14]. Lappet-faced vultures, one of the most aggressive vultures in Africa, have been filmed and recorded attacking and repelling jackals from carcasses [2,14,15]. There are no records of vultures killing jackals although martial eagles have killed Black-backed Jackals [16]. Golden jackals are noted to be aggressive competitors, and "can dominate even the largest vultures, and may hold dozens at bay while it monopolizes the remains of a kill, threatening, snapping, lunging with ears flattened and tail whipping from side to side, sometimes jumping into the air to bite at a bird that tries to land too close" [16]. As vultures may also dominate jackals, the relationship may also be termed indeterminate [17].

\section{Conclusions}

The evidence hints that the more eagle-like Old World vultures have a more equal relationship than the New World vultures with scavenging canids. Further study on this difference is important for three reasons. Vultures have declined in many Eurasian and African countries and canids (including feral dogs) have increased their scavenging role. Hence, a vulture population recovery must acknowledge the competitive role of canids. Also, as condor recovery programs are gathering ground in the Americas, the coyotes are possible impediments, possibly to a greater degree than jackals would be to old world vultures. Canids have a strong sense of smell and may precede vultures at hidden carcasses (condors and Old World vultures lack a sense of smell), hence when more visible carcasses are removed for sanitation purposes, conflicts may emerge between vultures and canids over the few remaining food sources. This encourages possibilities for detailed field research, which may increase our knowledge of the ecological relations of vultures and link the somewhat disparate studies of vulture evolution and biology with ecology and conservation possibilities.

\section{References}

1. Brown LH, Amadon D (1968) Eagles, Hawks and Falcons of the World. McGraw-Hill, New York.
2. Mundy P, Butchard D, Ledger J, Piper S (1992) The vultures of Africa. Academic Press, New York.

3. Del Hoyo J, Elliott A, Sargatal J (eds.) (1994) Handbook of birds of the world. Vol 2. New World vultures to guineafowl. Lynx Edicions, Barcelona, Spain

4. Krabbe N, Fjeldså J (1990) Birds of the High Andes. Apollo Press, Newport News.

5. Ryser FA, Ryser, FA Jr (1985) Birds of the Great Basin: A natural history. University of Nevada Press, Las Vegas.

6. Wilbur S, Jackson JA (1983) Vulture Biology and Management, University of California Press, Berkeley.

7. Wilmers, CC, Stahler, DR, Crabtree, RL, Smith D, Getz, WM (2003) Resource dispersion and consumer dominance: scavenging at wolf and hunter-killed carcasses in Greater Yellowstone, USA. Ecology Letters 6: $996-1003$.

8. Kendall CJ (2013) Alternative strategies in avian scavengers: how subordinate species foil the despotic distribution. Behavioral Ecology and Sociobiology 67(3): 383-393.

9. Koford CB (1953) The California Condor. General Publishing Company, Toronto.

10. Snyder NFR, Snyder H (2006) Raptors of North America: Natural History and Conservation. Voyageur Press, Minneapolis.

11. Meretsky VJ, Snyder NFR, Bessinger SR, Clendenen DA, Wiley JW (2000) Demography of California Condor: Implications for reestablishment. Conservation Biology 14(4): 957 - 967.

12. Rideout BA, Stalis I, Papendick R (2012) Patterns of mortality in freeranging California condors (Gymnogyps californianus). Journal of Wildlife Diseases 48(1): 95-112.

13. Kruuk H (1967) Competition for food between vultures in East Africa. Ardea 5:171 - 192.

14. Perry P (2007) Lappetfaced Vulture attacking Golden Jackal at Gnu carcass Locality Serengeti, Tanzania. http://ibc.lynxeds.com/photo/ lappet-faced-vulture-torgos-tracheliotus/lappetfaced-vulture-attackinggolden-jackal-gnu-carca Accessed 30/03.2014.

15. Daily Telegraph (2010) Vulture pictured fighting jackal for wildebeest 28 Jun 2010. Retrieved 24-015 2014. http://www.telegraph.co.uk/earth/ wildlife/7858482/Vulture-pictured-fighting-jackal-for-wildebeest.html.

16. Este R (1992) The behavior guide to African mammals: including hoofed mammals, carnivores, primates. University of California Press, Berkeley.

17. Shimelis A, Sande E, Evans S, Mundy P (eds.) (2005) International Species Action Plan for the Lappet-faced Vulture, Torgos tracheliotus BirdLife International, Nairobi, Kenya and Royal Society for the Protection of Birds, Sandy, Bedfordshire. 